\title{
Responsive Contrast Agents: Synthesis and Characterization of a Tunable Series of pH-Sensitive Near-Infrared Pentamethines
}

\author{
Virginia Wycisk, ${ }^{* \dagger}{ }^{\dagger}$ Katharina Achazi, ${ }^{\dagger}$ Paul Hillmann, ${ }^{\dagger}$ Ole Hirsch, ${ }^{\dagger}$ Christian Kuehne, ${ }^{\S}$ Jens Dernedde, ${ }^{\S}$ \\ Rainer Haag, ${ }^{\dagger}$ and Kai Licha* ${ }^{*} \dagger$ \\ ${ }^{\dagger}$ Institute of Chemistry and Biochemistry, Freie Universität Berlin, Takustr. 3, 14195 Berlin, Germany \\ ${ }^{\ddagger}$ Physikalisch-Technische Bundesanstalt, Abbestr. 2-12, 10587 Berlin, Germany \\ ${ }^{\S}$ Institute of Laboratory Medicine, Clinical Chemistry and Pathobiochemistry, Charité-Universitätsmedizin Berlin, Augustenburger \\ Platz 1, 13353 Berlin, Germany
}

\section{Supporting Information}

ABSTRACT: The demand for responsive dyes in optical imaging is high to achieve a better signal-to-noise ratio and, more specifically, to visualize acidic compartments of the endocytic pathway. Herein, we present a new synthetic route, with a step-bystep synthesis of water-soluble $\mathrm{pH}$-sensitive cyanine dyes exhibiting $\mathrm{p} K_{\mathrm{a}}$ values in the region of physiological $\mathrm{pH}$, as confirmed by absorption and fluorescence spectra. Moreover, modification of $\mathrm{p} K_{\mathrm{a}}$ values was achieved by two different substitution patterns, creating tunable $\mathrm{pH}$-sensitive dyes. We demonstrated the functionality of the $\mathrm{pH}$-sensitive dyes and their suitability as contrast agents for cellular uptake studies by preparing dye-labeled cetuximab and transferrin conjugates. Sulfonated head chains increased water solubility and prevented the formation of dimers, even in the context of dye-labeled bioconjugates. Confocal microscopy images of living cells revealed their $\mathrm{pH}$-responsiveness, as specific fluorescence signal enhancements were observed in acidic compartments of the endocytic pathway (endosomes and lysosomes), although the background signal was low in a $\mathrm{pH}$-neutral environment. Using mixtures of conjugates labeled with either a $\mathrm{pH}$-sensitive or non-pH-sensitive dye for the uptake studies, we could follow the receptor binding and distinguish it from the endocytic uptake process of the conjugates in a simultaneous manner. Moreover, we used flow cytometry to quantify the fluorescence and observed a 3 -fold signal enhancement for the $\mathrm{pH}$-sensitive dye conjugates over a period of $3 \mathrm{~h}$.

\section{INTRODUCTION}

Intracellular $\mathrm{pH}$ has been a focus in molecular biology studies, as it plays an important role in many cellular processes, such as signal transduction, ${ }^{1}$ ion transport, ${ }^{2}$ and enzyme activity, ${ }^{3}$ as well as in a cell's lifecycle; ${ }^{44}$ for example, cell proliferation and apoptosis is regulated by $\mathrm{pH}$ gradients. Moreover, abnormal $\mathrm{pH}$ values can be found in diseases such as Alzheimer's disease ${ }^{5}$ or cancer $^{6-9}$ in which extracellular $\mathrm{pH}$ is decreased compared to that in healthy tissue. Furthermore, cellular uptake mechanisms such as phagocytosis, endocytosis, and ligand-receptor complex internalization are known pathways that involve $\mathrm{pH}$ decrease during uptake and intracellular processing. ${ }^{10-13}$ Endocytosis is an active transport process that enables the uptake of large polar molecules that are unable to pass through the cell membrane. Compounds undergoing endocytosis are typically enclosed in membrane vesicles of different shapes and coatings. These bodies fuse with early endosomes, in which they are sorted and subsequently forwarded either to cellular compartments, such as the endoplasmic reticulum and Golgi apparatus, or to late endosomes and then lysosomes for degradation. ${ }^{4,14}$ Whereas the extracellular medium and cytosol exhibit a neutral $\mathrm{pH}$ (7.4), upon endocytosis, the intravesicular
$\mathrm{pH}$ decreases from neutral to $\mathrm{pH} 6$ in endosomes and reaches a minimum in lysosomes ( $\mathrm{pH} \mathrm{5)} .{ }^{15}$ In the past few years, many substances have been investigated for their cellular uptake characteristics. Among them is the monoclonal antibody cetuximab (ctx), which is known to bind to the epidermal growth factor receptor (EGFR) and subsequently internalize by endocytosis. ${ }^{16-18}$ Because EGFR is highly expressed on tumor cells, ctx has broad utility for cancer treatment, ${ }^{19,20}$ and it was approved by the Food and Drug Administration in 2004. However, there is still broad interest in studying cellular uptake in more detail.

Over the past few years, optical imaging has become a key tool for the investigation of biological processes by the use of various fluorophores. The application of near-infrared (NIR) dyes enables the use of low concentrations and nonionizing radiation, which makes them suitable for live-cell and in vivo imaging. ${ }^{21}$ However, the NIR dye indocyanine green is the only cyanine dye that has been clinically approved. ${ }^{22}$ Yet, its

Received: August 10, 2016

Accepted: September 20, 2016

Published: November 4, 2016 
application is hampered by its performance as an always-on probe that generates a high background signal versus barely detectable peak intensities at sites of activity. Therefore, there is a strong demand for responsive probes that exhibit fluorescence solely where they are active in a cell. Responsive probes are characterized by signal amplification caused by environmental triggers, including $\mathrm{pH}$ change, enzymatic modifications, or the detection of oxygen radicals. ${ }^{23} \mathrm{pH}$-responsive dyes specifically allow us to follow $\mathrm{pH}$ changes during cellular uptake due to the modulation of the emission spectrum upon acidification. Recently, a variety of responsive dyes have been developed, such as carboxyfluorescein ${ }^{24}$ and boron-dipyrromethene, ${ }^{25,26}$ which are also used for staining cell compartments, for example, LysoTracker Green DND-26. ${ }^{27}$ Among these are polymethine cyanine dyes, which are broadly applied because of their good photostability. In addition, polymethine dyes exhibit a flexible structure, which offers the opportunity to tune water solubility and spectroscopic properties through a variety of pre- and postsynthetic modifications. To date, only a small set of $\mathrm{pH}$ sensitive cyanine dyes based on trimethines, pentamethines, or heptamethines have been developed. ${ }^{28-35}$ CypHer5E (GE Healthcare Life Sciences) is the only commercially available responsive cyanine dye that exhibits $\mathrm{p} K_{\mathrm{a}}$ values in the range of physiological $\mathrm{pH}$. Intensive studies revealed the $\mathrm{pH}$ dependence of the fluorophore and confirmed the suitability of the sensor for in vitro and in vivo applications. ${ }^{36-44}$ However, CypHer5E has a low solubility in aqueous media and requires the use of dimethyl sulfoxide (DMSO) for optimal solubilization. Organic solvents are usually toxic to cells, although, depending on the cell line, a low percentage of DMSO is still tolerated in vitro. ${ }^{45,46}$ Therefore, an unmet need exists for water-soluble dyes with $\mathrm{pH}$-tunable fluorescence. Herein, we report a tunable set of $\mathrm{pH}$-sensitive cyanine dyes incorporating three sulfonate groups to increase water solubility and prevent aggregation. Furthermore, a carboxy functionality enables conjugation to carriers or target molecules. Because of an additional benzene moiety, a bathochromic shift allows for optimized fluorescence imaging of living cells close to the optical window. Moreover, we prepared $\mathrm{pH}$-sensitive dyes with different $\mathrm{p} K_{\mathrm{a}}$ values by modifying the meso-position of the conjugated polymethine chain. Applying qualitative and quantitative measurements through confocal laser scanning microscopy (cLSM) images and flow cytometry, we characterized the novel $\mathrm{pH}$-sensitive dyes as fluorescent labels that are highly suitable to monitor cellular binding and study uptake processes (Figure 1).

\section{RESULTS AND DISCUSSION}

Dye Synthesis. We synthesized a new set of water-soluble pentamethine dyes that consist of sulfonated benzindolenine $\mathbf{1}$ and unalkylated or methylated carboxy indolenine precursors. The synthesis was carried out using 2-chloromalondianil 2 and 3-anilinoacrolein anil 3 to afford chloro-substituted derivatives 6 and 7 and nonsubstituted dyes 8 and 9, respectively. Fluorophores 7 and 9 form a pair of non-pH-sensitive dyes that are structurally similar to the $\mathrm{pH}$-dependent dyes but insensitive to $\mathrm{pH}$ changes due to the methyl-blocked nitrogen atom. Through the introduction of an additional benzene moiety using benzindolenine 1 as a precursor in the cyanine synthesis, a bathochromic shift of nearly $20 \mathrm{~nm}$ compared to CypHer5E was achieved, allowing for optimized optical imaging. The benzindolenine precursor is also equipped with three sulfonic acid groups, yielding highly hydrophilic

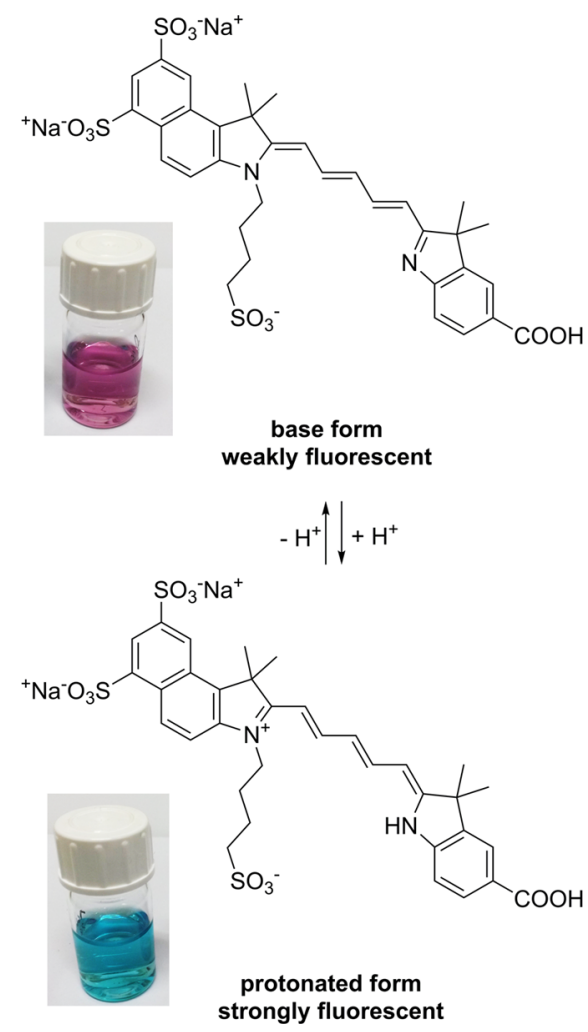

Figure 1. Structural change of the conjugated system upon protonation of the weakly fluorescent base form (red) into the fluorescent dye (blue).

fluorophores due to negative charges that are known to prevent dimerization. Furthermore, functionalizing the other indolenine enables conjugation of the dyes to targeting moieties, for example, biomolecules.

The first step of the synthesis was carried out in a microwave system using the less-reactive sulfonated benzindoleine, $\mathbf{1}$, and acroleine derivative $\mathbf{2}$ or $\mathbf{3}$ dissolved in acetic acid to form an intermediate, which was separated from the unreacted starting material by precipitation in diethyl ether. Chromatographic purification could not be performed because of fast decomposition on silica gel. In the next step, unalkylated $\mathbf{4}$ or methylated carboxy indolenine $\mathbf{5}$ was added along with sodium acetate, and the reaction was carried out in methanol at $90{ }^{\circ} \mathrm{C}$ overnight (see Scheme 1). After purification by reversed phase (RP) high-performance liquid chromatography (HPLC), the hydrophilic pentamethine dyes were obtained in yields ranging from 7 to $42 \%$, and the purity was confirmed by NMR and analytical HPLC (see the Supporting Information, Figures S1S10). Moreover, we designed four chromophores based on a benzindole moiety providing three sulfate groups, enabling similar degrees of hydrophilicity, as proven by HPLC retention in comparison to that for CypHer5E (see Figures S7-S11).

For cellular uptake studies, the newly synthesized fluorophores were conjugated to biomolecules to follow the emission signal and evaluate the new dyes as $\mathrm{pH}$ sensors in vitro. As model molecules, we chose the iron-binding plasma protein transferrin (tf) and ctx, a monoclonal IgG antibody. Both ligand molecules are known to enter the cell via receptor-mediated endocytosis. In contrast to tf, which is recycled and transported back to the extracellular environment after release of bound iron in early endosomes, ctx binds to the EGF receptor and ends up in lysosomes. ${ }^{4,47,48}$ Therefore, lysosomal accumulation 
Scheme 1. Synthesis of Pentamethine Dyes 6-9 and Their Conversion into N-Hydroxysuccinimide (NHS) Esters 10-13 ${ }^{a}$
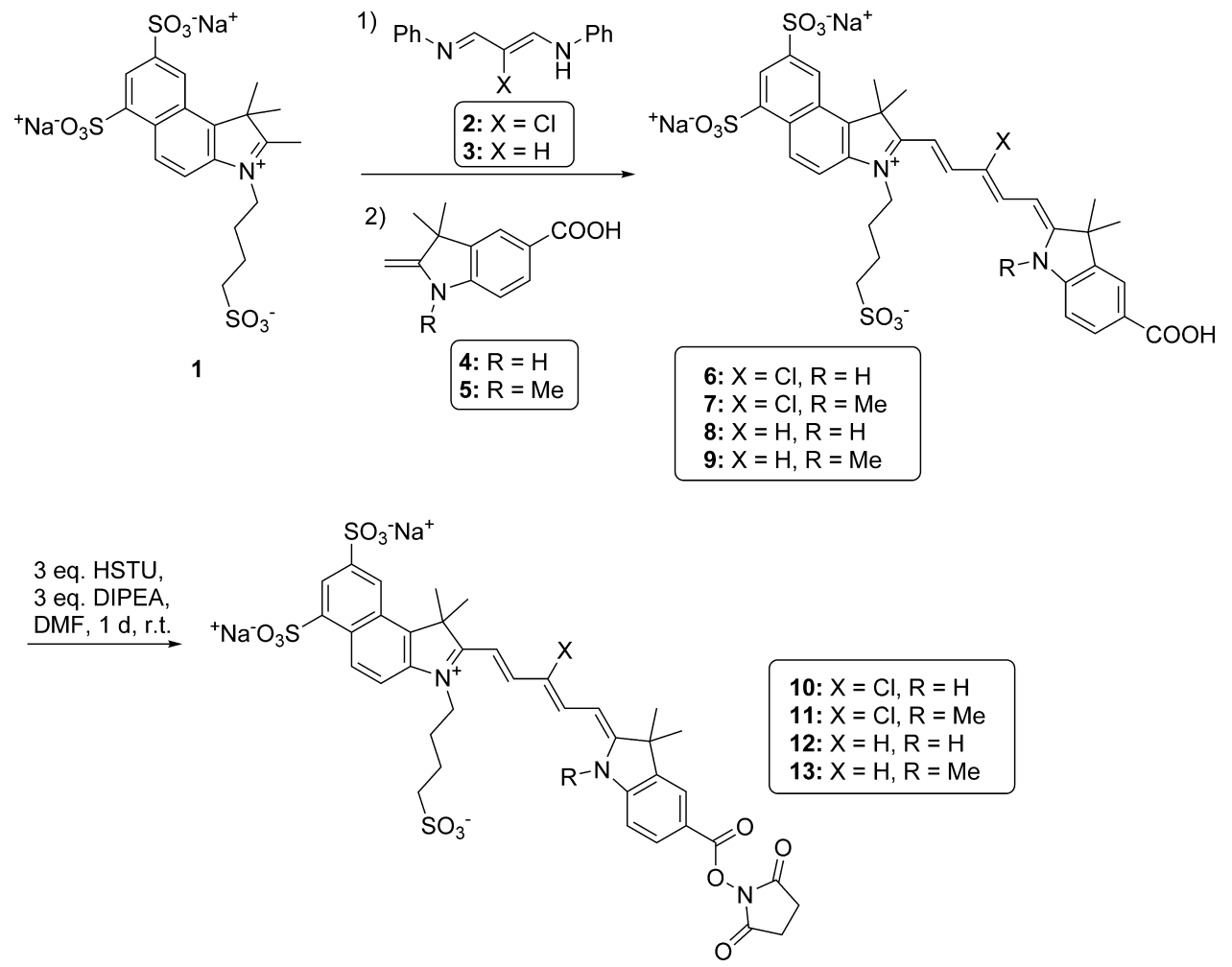

${ }^{a}(1)$ Microwave, acetic acid, $110{ }^{\circ} \mathrm{C}, 2 \mathrm{~h}$; (2) sodium acetate, methanol, $90^{\circ} \mathrm{C}$, overnight.

Table 1. Spectroscopic Properties of Free Dyes 6-9 and Dye-Labeled tf and ctx Conjugates

\begin{tabular}{|c|c|c|c|c|c|c|c|}
\hline compound & $\lambda_{\mathrm{abs}}, \mathrm{nm}$ & $\lambda_{\mathrm{em}}, \mathrm{nm}$ & Stokes shift, nm & $\varepsilon\left(\lambda_{\mathrm{abs}, \max }\right)^{a}$ & $\Phi_{\mathrm{f}}$ & $B^{b}$ & $\mathrm{D} / \mathrm{P}$ \\
\hline 6 & $662^{c}$ & $684^{c}$ & $22^{c}$ & $142000^{c}$ & $0.12^{c}$ & $17000^{c}$ & \\
\hline 7 & $662^{d}$ & $686^{d}$ & $24^{d}$ & $182000^{d}$ & $0.12^{d}$ & $22000^{d}$ & \\
\hline 8 & $662^{c}$ & $685^{c}$ & $23^{c}$ & $140000^{c}$ & $0.22^{c}$ & $31000^{c}$ & \\
\hline 9 & $662^{d}$ & $688^{d}$ & $26^{d}$ & $220000^{d}$ & $0.24^{d}$ & $53000^{d}$ & \\
\hline $10-t f$ & 664 & 681 & 14 & & & & 1.0 \\
\hline $11-\mathrm{tf}$ & 666 & 695 & 29 & & & & 1.4 \\
\hline $12-\mathrm{tf}$ & 664 & 687 & 24 & & & & 1.0 \\
\hline $13-t f$ & 664 & 688 & 24 & & & & 0.9 \\
\hline ICC $-\mathrm{tf}$ & 552 & 571 & 19 & & & & 0.7 \\
\hline $10-\operatorname{ctx}$ & 667 & 685 & 18 & & & & 1.0 \\
\hline $11-\mathrm{ctx}$ & 667 & 691 & 24 & & & & 0.7 \\
\hline $12-c t x$ & 668 & 686 & 21 & & & & 1.4 \\
\hline $13-c t x$ & 665 & 693 & 28 & & & & 1.0 \\
\hline ICC - ctx & 552 & 565 & 13 & & & & 0.9 \\
\hline
\end{tabular}

${ }^{a}$ Molar absorption coefficient $\varepsilon\left(\lambda_{\mathrm{abs}, \max }\right)$ in $\mathrm{L} \mathrm{mol}^{-1} \mathrm{~cm}^{-1}$. ${ }^{b}$ Brightness $B\left(B=\varepsilon\left(\lambda_{\mathrm{abs}, \max } \cdot \Phi_{\mathrm{f}}\right) \cdot{ }^{c}\right.$ Phosphate buffer, $\mathrm{pH}=5.5 .{ }^{d} \mathrm{Phosphate}$ buffer, $\mathrm{pH}=$ 7.5 .

of ctx dye conjugates should lead to an increase in the fluorescent signal. For bioconjugation, the carboxy functionalities of dyes 6-9 were converted into the more reactive NHS esters using HSTU or dicyclohexylcarbodiimide (DCC)/NHS, yielding the respective esters $(10-13)$ in $64-99 \%$ yield. Subsequently, the NHS esters were reacted with tf or ctx overnight in phosphate-buffered saline (PBS) ( $\mathrm{pH}=7.4$ ), without the requirement of any organic co-solvents, and yielded conjugates with similar dye-to-protein $(\mathrm{D} / \mathrm{P})$ ratios, ranging from 0.7 to 1.4 (see Table 1). In addition to the newly synthesized fluorophores, we also prepared conjugates with indocarbocyanine (ICC) ${ }^{49}$ for spectroscopic comparison. The absence of free dye in ctx conjugates as well as covalent coupling of the dyes to the heavy and light chains of ctx was confirmed by gel electrophoresis. Moreover, surface plasmon resonance (SPR) measurements revealed retained functionality upon labeling. EGF receptor recognition of ctx and the dye conjugates gave comparable affinity constants (see Figures S14-S16 and Table S1).

Spectroscopic Characterization. The newly synthesized dyes showed excellent water solubility and therefore the spectroscopic characterization could be performed in aqueous media, which is required for the evaluation of $\mathrm{pH}$ dependency. Absorption and fluorescence spectra were recorded in different phosphate buffer solutions, ranging in $\mathrm{pH}$ from 5.0 to 10.0 (shown in Figure 2). In buffer solution $(\mathrm{pH}=5.5-6.0), \mathrm{pH}$ - 

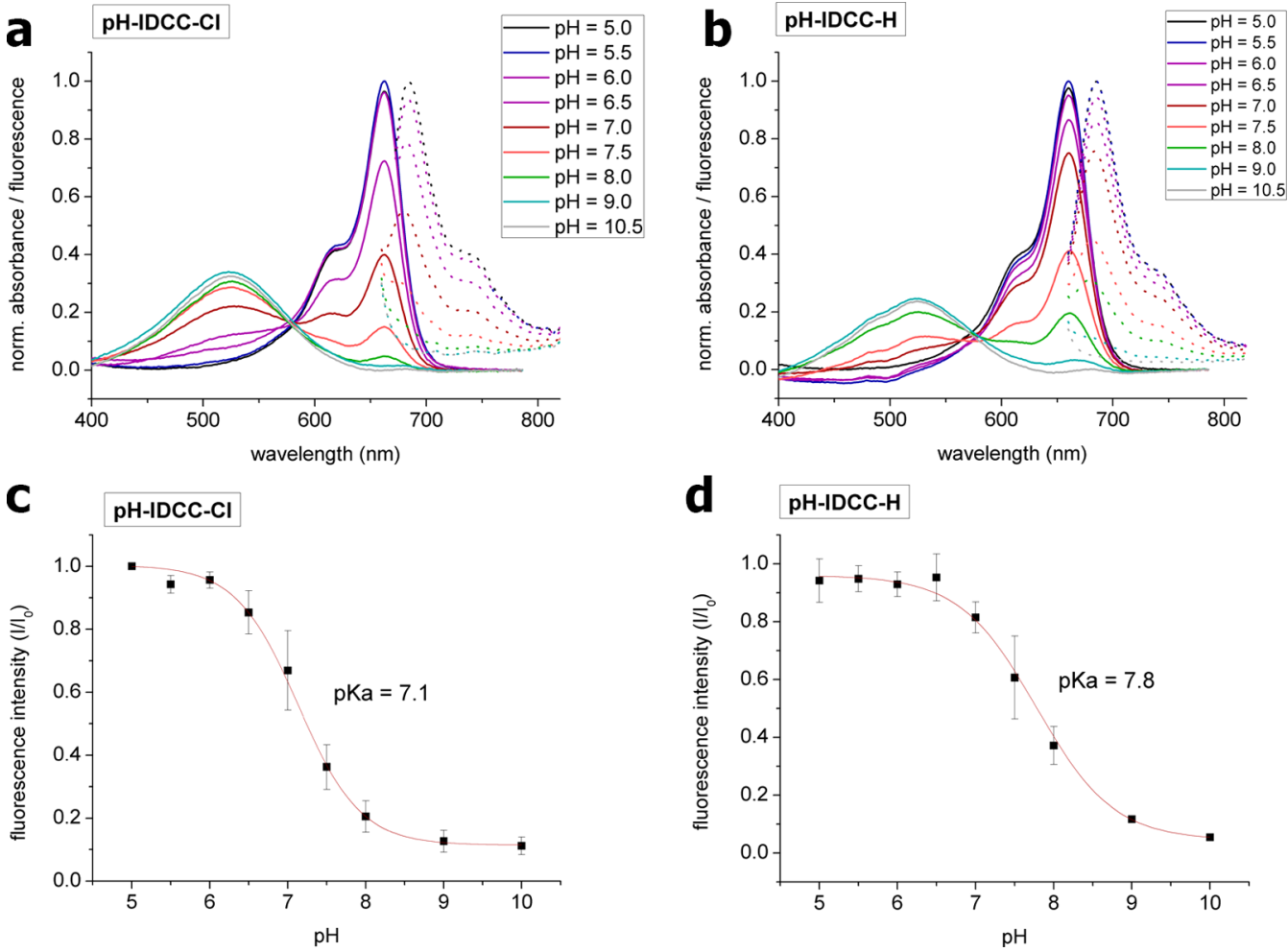

Figure 2. Absorption and fluorescence spectra of dyes 6 (a) and 8 (b) in phosphate buffer solution. Graphs (c) and (d) show the pH dependence of the fluorescence maxima at 684 and $685 \mathrm{~nm}$ of dyes 6 and 8, respectively. $\mathrm{p} K_{\mathrm{a}}$ values displayed in graphs (c) and (d) were determined by a fitting curve from triplicate measurements.

sensitive dyes 6 and 8 reveal absorption maxima at $662 \mathrm{~nm}$, which decrease with rising $\mathrm{pH}$. A remarkable drop to $30 \%$ fluorescence intensity between pH's 5.0 and 7.5 is obvious, and coincidentally, a new peak at $520 \mathrm{~nm}$ arises at $\mathrm{pH}>6.0$, originating from the nonfluorescent base form. Although chloro-substituted dye 8 shows similar results to dye 6 , the absorption maximum of the protonated form was detected up to $\mathrm{pH} 7.5$, whereas that of the base form is detectable from $\mathrm{pH}$ 7.0 onwards. We observed a decrease in fluorescence intensity up to $\mathrm{pH}$ 8.0. The $\mathrm{pH}$ dependency of dyes conjugated to $\mathrm{ctx}$ or tf revealed a similar peak pattern as that for free dyes, which is illustrated in the Supporting Information (see Figure S12). Additionally, aggregation was not observed for free dyes, and only minimal dimerization was detected in bioconjugates. By comparing fluorescence maxima at different $\mathrm{pH}$ values, we determined $\mathrm{p} K_{\mathrm{a}}$ values of 7.1 and 7.8 for dyes 6 and 8 , respectively (see Figure $2 \mathrm{c}, \mathrm{d}$ ), from fluorescence spectra, whereas absorption spectra revealed $\mathrm{p} K_{\mathrm{a}}$ values of 6.9 and 7.5 (see Figure S13). These values are similar to the $\mathrm{p} K_{\mathrm{a}}$ of 7.3 that was reported for CypHer5E by GE Healthcare Life Sciences. Moreover, the $\mathrm{p} K_{\mathrm{a}}$ of the newly synthesized chloro-derivative 6 even falls below the value for CypHer5E. To conclude, the $\mathrm{pH}$ dependency was influenced by different residues at the mesoposition of the conjugated chain, as the chloro atom in dye 6 most likely withdraws electron density from the conjugated system. In contrast, non-pH-sensitive dyes 7 and 9 revealed constant absorption maxima in buffer solutions.

Spectroscopic data of dyes 6-9 are summarized in Table 1 and are in good accordance with those for known pentamethine dyes, ${ }^{50-52}$ revealing molar absorption coefficients of $\sim 140000$ for $\mathrm{pH}$-sensitive dyes $\mathbf{6}$ and $\mathbf{8}$ and larger coefficients for non$\mathrm{pH}$-sensitive dyes 7 and 9. Fluorescence quantum yields are also comparable to those of other pentamethine dyes, whereas chloro-substituted dyes 6 and 7 exhibit lower $\Phi_{\mathrm{f}}$ values $(0.12)$ than those of nonsubstituted dyes 8 and 9 , for which we determined $\Phi_{\mathrm{f}}$ to be $\sim 0.23$. The substitution of the polymethine chain influences $\Phi_{\mathrm{f}}$, leading to a decrease when an electron-withdrawing group is introduced, which was also observed by Mader et al. ${ }^{51}$ Moreover, each $\mathrm{pH}$-sensitive dye reveals the same $\Phi_{\mathrm{f}}$ as that of its structurally similar reference dye. Additionally, all dyes reveal bathochromic-shifted absorption maxima at $662 \mathrm{~nm}$, caused by the additional benzene ring on the indolenine moiety.

Cellular Uptake Studies. Biological evaluation of the new fluorophores was conducted by cellular uptake studies using cLSM and flow cytometry. tf and ctx are prominent molecules referenced in the literature due to their well-known cellular uptake pathways via receptor-mediated endocytosis. Moreover, ctx binds to the EGFR, which is highly expressed on the A431 epidermoid cancer cell line, whereas low-EGFR-expressing A549 lung cancer cells can be used as the control cell line. In theory, dye-labeled conjugates are internalized after receptor binding, and $\mathrm{pH}$-sensitive dyes are supposed to reveal an enhanced emission signal during intracellular processing in endosomes and lysosomes. $\mathrm{tf}$ is known to be shuttled back to the neutral extracellular environment after iron release due to acidification in the early endosomes. ${ }^{48}$ In contrast, EGFRbinding proteins, such as ctx, accumulate in lysosomes. ${ }^{47}$ Therefore, cells incubated with ctx conjugates labeled with $\mathrm{pH}$ sensitive dyes should show an intracellular increase in the fluorescence signal over time. In contrast, no signal enhancement is expected for $\mathrm{pH}$-sensitive tf conjugates. In the present study, cLSM was used to image living (nonfixed) cells because $\mathrm{pH}$ changes might occur during cell fixation. In all experiments, 

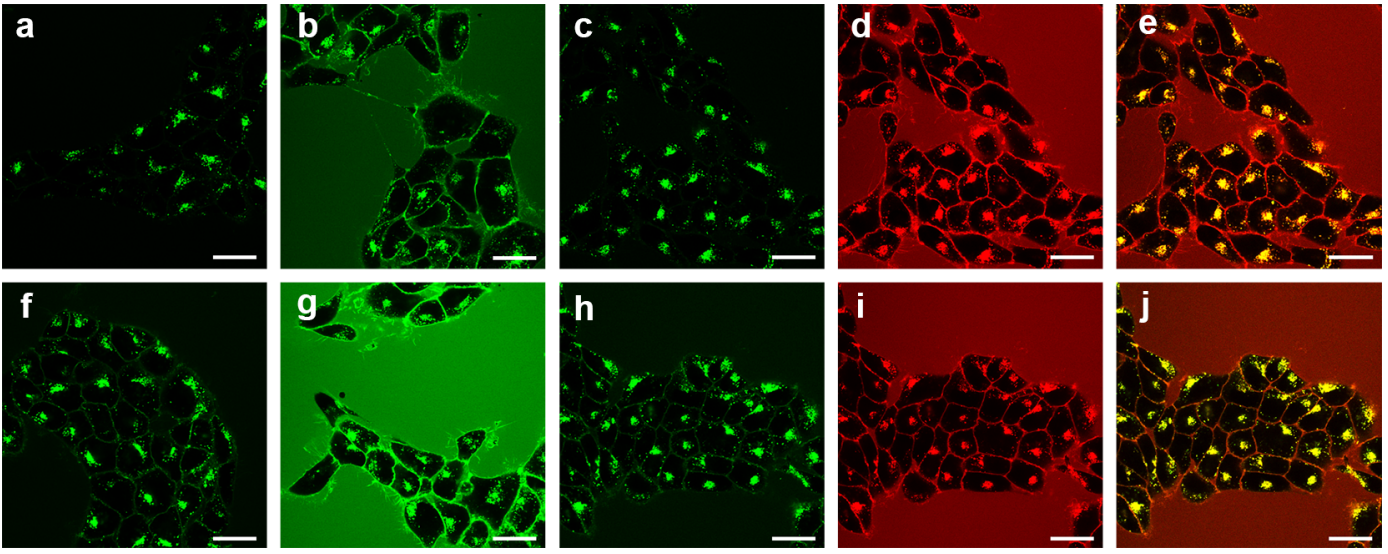

Figure 3. Live-cell images of A431 cells incubated for $4.5 \mathrm{~h}$ with conjugates 10-ctx (a), 11-ctx (b), 12-ctx (f), and 13-ctx (g). Images (c)-(e) and $(\mathrm{h})-(\mathrm{j})$ show living cells incubated with previously mixed conjugates consisting of ICC $-\mathbf{t f}((\mathrm{d})$ or $(\mathrm{i}))$ and $\mathbf{1 0}-\mathbf{t f}(\mathrm{c})$ or $\mathbf{1 2}-\mathbf{t f}(\mathrm{h})$ containing $\mathrm{pH}$-sensitive dyes. Images (d) and (i) represent channels for ICC-ctx, whereas (e) and (j) show the overlay of both channels. Scale bars equal 30 $\mu \mathrm{m}$.
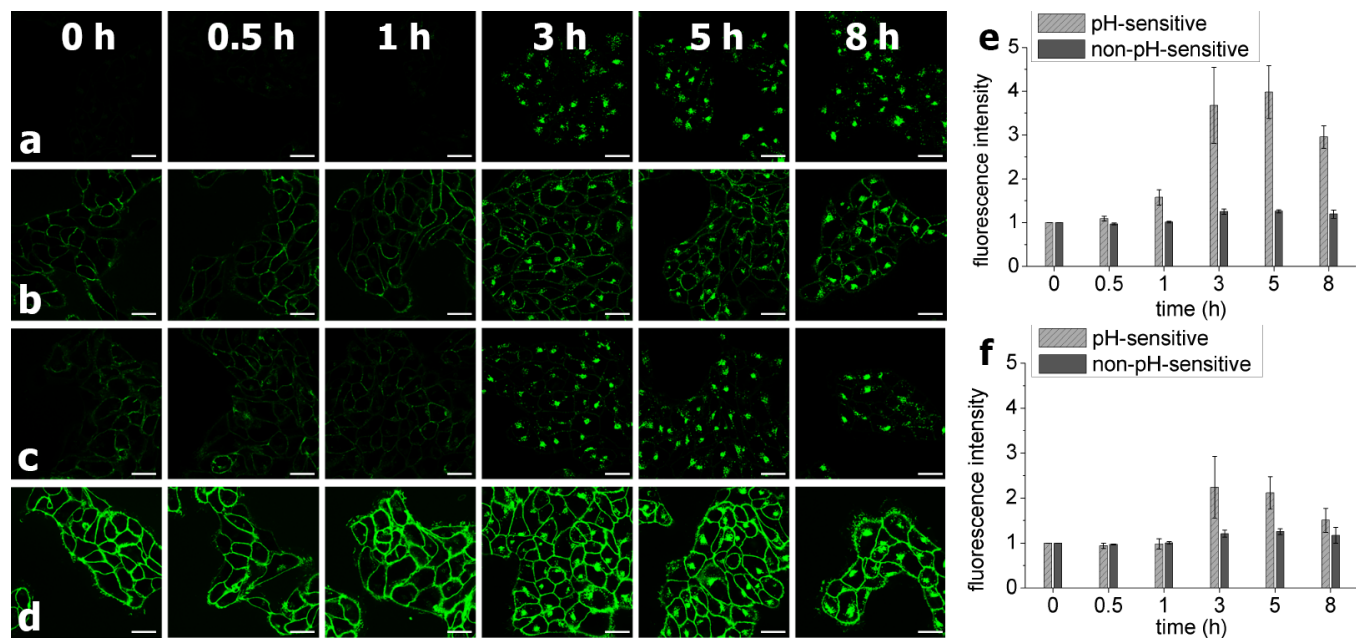

Figure 4. Confocal images of living A431 cells incubated for $10 \mathrm{~min}$ with dye-labeled ctx conjugates. Images were taken after a washing step at different times, showing pH-sensitive dyes 10-ctx (a) and 12-ctx (c) and reference dyes 11-ctx (b) and 13-ctx (d). Scale bars equal $30 \mu \mathrm{m}$. Flow cytometry results are illustrated in graphs (e) and (f): conjugates 10-ctx and 11-ctx (e) and 12-ctx and 13-ctx (f). Each bar represents the mean fluorescence intensity based on five independent measurements, with error bars given as standard errors of the mean. The fluorescence was normalized to the starting points ( $0 \mathrm{~h}$ after the washing step).

we used concentrations of $1 \mu \mathrm{M}$ on the basis of the dye's absorption maximum, and because of similar $\mathrm{D} / \mathrm{P}$ ratios, they were even comparable to the ctx or tf concentration (see Table 1). A431 cells were incubated with dye-labeled tf and ctx conjugates for 2.5 and $4.5 \mathrm{~h}$, respectively, without a washing step. As shown in Figure 3, conjugates 10-ctx (a) and 12-ctx (f), which contain $\mathrm{pH}$-sensitive dyes, revealed a very low background signal, which is in the range of autofluorescence of cells, but strong emission was observed inside acidic cellular compartments. Comparing both $\mathrm{pH}$-sensitive dyes, the nonsubstituted derivative, 12-ctx, revealed a slightly higher background signal, which can be associated with the increased $\mathrm{pK}_{\mathrm{a}}$ value of the respective free dye, 8 . In contrast, the non-pHsensitive dye-labeled conjugates, 11-ctx (b) and 13-ctx (g), revealed a strong background signal as well as accumulation inside cellular compartments, whereas conjugate 13-ctx shows enhanced fluorescence intensity, most likely due to the higher $\Phi_{\mathrm{f}}$ of the corresponding free dye, 9. Moreover, all dye-labeled ctx conjugates show the characteristic cytoplasmic membrane staining of EGFR on A431 cells before internalization, with the exception of $\mathrm{pH}$-sensitive dye conjugate $10-\mathrm{ctx}$, due to the smaller $\mathrm{p} K_{\mathrm{a}}$ value of the respective free dye, 6 , which is caused by the chloro atom in the conjugated chain. Accordingly, conjugate 10-ctx is more selective for intracellular detection in acidic vesicles and exhibits only a low background signal under physiological conditions. Even though fluorescence is still present at physiological $\mathrm{pH}$, as we reported in the fluorescence spectra of the free dyes (see Figure $2 a, b$ ), we could observe only a very weak signal, which was below the detection limit of the microscope. In our experiments, the lasers were set to allow sensitive detection above autofluorescence of cells and therefore the background signal is negligible, particularly when compared to that of reference dyes. Images of $t f$ conjugates showed similar results and are displayed in Figures S18 and S19); in addition, images obtained for A549 cells incubated with tf and ctx conjugates are shown in Figures S21 and S22.

To further strengthen our results, we utilized ICC-labeled conjugates ICC-tf and ICC-ctx, which are insensitive to $\mathrm{pH}$ changes and additionally enabled simultaneous measurements 
of both dyes in equal environments due to a blue-shifted emission in the $\mathrm{Cy} 3$ spectral range, with negligible crosstalk to the spectral range of the $\mathrm{pH}$-sensitive dyes. Prior to incubation, conjugate ICC-ctx was mixed with conjugate $10-$ ctx or 12ctx, containing $\mathrm{pH}$-sensitive dyes, and the cellular uptake was followed by cLSM of living cells. After $4.5 \mathrm{~h}$, an accumulated signal was observed inside the cells for the ICC channel (see Figure 3d,e) and for red-shifted $\mathrm{pH}$-sensitive dye conjugates 10-ctx (3c) and 12-ctx (3h). Whereas the $\mathrm{pH}$-sensitive dyes revealed a weak signal in extracellular medium, the ICC conjugates showed strong background signals as well as characteristic receptor binding on membranes. Moreover, overlaid channels revealed co-localization inside the cells. Furthermore, we also incubated the cells with LysoTracker Green DND-26, which stains acidic compartments inside the cells. For all conjugates, we could see a good correlation among the dyes (see Figure S20).

For quantitative assessment of the new fluorophores, we also used flow cytometry and investigated the amount of fluorescent cells. Because of the rapid cellular uptake of tf and its fast recycling back to the cell surface, ${ }^{4,48}$ no signal increase could be observed (see Figure S17). Therefore, further studies were conducted with ctx conjugates. EGFR-positive A431 cells were incubated with ctx conjugates for $10 \mathrm{~min}$, followed by a washing step. Fluorescence of the cells was analyzed over a period of $8 \mathrm{~h}$ and normalized to the starting point $(0 \mathrm{~h}$ after the washing step) to follow the signal enhancement caused by cellular uptake in a comparable manner. Figure $4 \mathrm{e}, \mathrm{f}$ illustrates a strong increase in the fluorescence intensity up to $3 \mathrm{~h}$ for $\mathrm{pH}$-sensitive conjugates and a signal decrease after $5 \mathrm{~h}$, whereas the non-pHsensitive dyes revealed a nearly constant signal. Whereas nonsubstituted dye conjugate $12-$ ctx exhibited a 2.5 -fold signal increase, Cl-substituted dye conjugate 10-ctx demonstrated a 3.5-fold signal enhancement. These results are consistent with our previous observations and underline the potential of chloro-substituted $\mathrm{pH}$-sensitive dye $\mathbf{6}$ in cellular uptake studies, given its lower $\mathrm{p} K_{\mathrm{a}}$ value of 7.1 compared to that of nonsubstituted dye 8. To interpret the results obtained from flow cytometry analysis, we followed the cellular uptake of ctx conjugates over a period of $8 \mathrm{~h}$ by cLSM of living cells. The procedure was similar to flow cytometry measurements and included a washing step after $10 \mathrm{~min}$ of incubation. Figure 4 shows the time-resolved cellular uptake of conjugates 10-ctx (a), 11-ctx (b), 12-ctx (c), and 13-ctx (d). A strong signal enhancement inside the cells is observed at $3 \mathrm{~h}$ and maintained up to $8 \mathrm{~h}$, strengthening the results from flow cytometry analysis. Moreover, characteristic membrane EGFR binding was observed for all conjugates, with the exception of $\mathrm{pH}$-sensitive dye conjugate 10-ctx, which exhibits the lowest background signal at physiological $\mathrm{pH}$. In contrast, membrane binding was observed up to $8 \mathrm{~h}$ for non-pH-sensitive dyes and contributes to the emission signal that was detected by flow cytometry and therefore has to be considered for the interpretation of quantitative results. Only the $\mathrm{pH}$-sensitive conjugate $10-$ ctx produced fluorescence, mostly from inside the cell. These findings are supported by accompanying spectroscopic studies of nonconjugated $\mathrm{pH}$-sensitive dye 6 , with a $\mathrm{p} K_{\mathrm{a}}$ value of 7.1, that can be used for monitoring cellular uptake without exhibiting strong fluorescence emission in the cell medium. In contrast, $\mathrm{pH}$-sensitive dye 8 revealed a higher $\mathrm{p} K_{\mathrm{a}}$ value and therefore in the context of conjugate $\mathbf{1 2 - c t x}$ demonstrates fluorescence emission at the cell membrane, while showing a low background signal in cell culture medium.

\section{CONCLUSIONS}

In summary, we successfully provided a new synthetic route to new $\mathrm{pH}$-sensitive cyanine dyes and also structurally similar reference dyes. For the first time, we describe a step-by-step synthesis of CypHer5E analogues with similar structural patterns. Moreover, we synthesized dyes with different substitution patterns at the meso-position of the conjugated chain, bearing a $\mathrm{Cl}$ or $\mathrm{H}$ atom, therefore resulting in a tunable $\mathrm{pH}$ dependence. The incorporation of three sulfonate groups resulted in excellent water solubility and low aggregation in aqueous solution. Successful functionalization with reactive NHS esters and subsequent conjugation to the biomolecules $t f$ and ctx was conducted. $\mathrm{p} K_{\mathrm{a}}$ values of 7.1 fell below the value for CypHer5E, whereas similar polarities were achieved. Additionally, the $\mathrm{pH}$-sensitivity was not only confirmed by absorption and fluorescence spectroscopy but the sensor properties were also evaluated by labeling of living cells. Flow cytometry measurements revealed an approximately 3 -fold increase in the emission signal after a $3 \mathrm{~h}$ incubation and a decrease in the signal at $8 \mathrm{~h}$. We also confirmed that the emission signal inside living cells can be tracked over time using confocal microscopy. In doing so, we showed that receptor-mediated binding and uptake can be visualized precisely as a fluorophore converts from low fluorescence emission at physiological $\mathrm{pH}$ to stronger emission in acidic compartments. Hence, our results demonstrate how the chemistry of $\mathrm{pH}$-sensitive cyanine dyes can be used to customize sensor properties using well-chosen structural substitution patterns and therefore allow, for the first time, insights into rational design of $\mathrm{pH}$ properties. Such dyes can be applied as contrast agents for various applications, for example, monitoring cellular uptake, as $\mathrm{p} K_{\mathrm{a}}$ value differences can be used to accentuate membrane binding and suppress background in the cell culture medium.

\section{METHODS}

Synthesis. All solvents and chemicals were commercially purchased from Sigma-Aldrich, VWR, Merck, and Acros Organics and used as received, unless otherwise stated. HSTU was bought from Carbolution, and compound 1 was purchased from Syntharo Fine Chemicals GmbH. 2-Chloromalondianil 2 and anilinoacrolein anil 3 were acquired from Organica. Indolenines $\mathbf{4}$ and $\mathbf{5}$ and ICC NHS were provided by Epiios Therapeutics GmbH. LysoTracker Green DND-26 was bought from Thermo Fisher Scientific. Erbitux was purchased from Merck Serono, and ctx was isolated by ultracentrifugation and lyophilization. Synthesized pentamethine dyes were purified by preparative HPLC on a high-pressure gradient system (stainless steel), equipped with dual Shimadzu LC-8A pumps, a Shimadzu CBM-20A controller, a variable wavelength UV detector from Knauer, and a Rheodyne injector with a 10 $\mathrm{mL}$ sample loop. The stationary phase was a prepacked RP-18 column (RSC-Gel, $5 \mu \mathrm{m}, 20 \times 250 \mathrm{~mm}^{2}$ ) from RSC. HPLC runs were performed with a total flow rate of $20 \mathrm{~mL} \mathrm{~min}$, applying a gradient from 10 to $100 \% \mathrm{MeOH}$, with UV detection at $650 \mathrm{~nm}$. Pure dyes were dried on a Virtis Benchtop $\mathrm{K} 20 \mathrm{~K} \mathrm{XL}$, and the purification of biomolecule conjugates was conducted on Sephadex columns (NAP-25, Sephadex G-25 DNA) with PBS as a solvent. Sensitive substances were shaken on BioShake $\mathrm{iQ}$ and centrifugation was conducted on Universal 32 from Hettich. All samples were weighed on Precisa XB120A, and for thin-layer chromatography (TLC), silica gel $60 \mathrm{RP}-18 \mathrm{~F}_{254} \mathrm{~S}$ plates were used for $\mathrm{RP}$ analysis. ${ }^{1} \mathrm{H}$ 
NMR spectra were recorded on a Bruker Avance III spectrometer $(700 \mathrm{MHz})$, and mass spectra were obtained via electrospray on an Agilent 6210 ESI-TOF spectrometer.

Absorption and Fluorescence Measurements. Samples for absorption and fluorescence measurements were dissolved in Millipore water or PBS solution $(3 \mathrm{mM} \mathrm{KCl}, 140 \mathrm{mM} \mathrm{NaCl}$, $0.01 \mathrm{M} \mathrm{Na} \mathrm{HPO}_{4} \cdot 7 \mathrm{H}_{2} \mathrm{O}$ in $500 \mathrm{~mL}$ distilled water) or previously prepared phosphate buffers $(67 \mathrm{mM}$, containing $\mathrm{Na}_{2} \mathrm{HPO}_{4} \cdot 2 \mathrm{H}_{2} \mathrm{O}$ and $\mathrm{KH}_{2} \mathrm{PO}_{4}$ in distilled water). All absorption spectra were recorded on a PerkinElmer LAMBDA $950 \mathrm{UV} /$ vis/NIR spectrometer, using disposable cuvettes from Brand, and fluorescence spectra were recorded on a Quantamaster 400 fluorometer. Absolute fluorescence quantum yields were calculated from previously recorded fluorescence spectra using a Fluorolog 3 fluorometer (Horiba Jobin Yvon) with an integrating sphere $(80 \mathrm{~mm}$ diameter, handmade). The light intensity was reduced by a neutral density filter $(10 \%$ transmission). Slit widths were set to $2.5 \mathrm{~nm}$ (excitation) and $1 \mathrm{~nm}$ (emission). All samples were excited at $640 \mathrm{~nm}$, and the integration time was set to $2 \mathrm{~s}$. For the determination of $\Phi_{\mathrm{f}}$, the integrated fluorescence values of the sample and solvent were determined to achieve the number of photons emitted (645$840 \mathrm{~nm}$, step size: $2 \mathrm{~nm}$ ) and absorbed (636-644 nm, step size: $0.2 \mathrm{~nm}$ ).

Synthesis of Dye Labels. Synthesis of Pentamethine Dyes 6-9. A mixture of 1-(4-sulfonatobutyl)5,7-disulfo-TMBI sodium salt $(0.182 \mathrm{mmol})$, acroleine 2 or $3(0.218 \mathrm{mmol})$, and $1 \mathrm{~mL}$ of acetic acid was added to a $0.5-2 \mathrm{~mL}$ reaction vial and heated in a microwave system to $110{ }^{\circ} \mathrm{C}$ for $2 \mathrm{~h}$. The solution was concentrated in vacuum, precipitated in ethyl ether, and centrifuged. To the residue, indolenine 4 or 5 ( 0.273 or 1.092 mmol), sodium acetate $(0.546 \mathrm{mmol})$ and $5 \mathrm{~mL}$ of methanol were added, and the mixture was heated to $90{ }^{\circ} \mathrm{C}$ overnight. The dye was precipitated in diethyl ether and centrifuged, and the residue was purified by HPLC using water/methanol.

Dye 6 was synthesized according to the above-described procedure, using 2-chlormalodianil 2 as acroleine and indolenine $4(1.092 \mathrm{mmol})$ in the second step of the reaction, affording dye 6 as a blue solid (46.3 mg, 31\%). ${ }^{1} \mathrm{H}$ NMR (700 $\left.\mathrm{MHz}, \mathrm{DMSO}-d_{6}\right) \delta 8.84(\mathrm{~d}, J=9.1 \mathrm{~Hz}, 1 \mathrm{H}), 8.32(\mathrm{~s}, 1 \mathrm{H})$, $8.06-7.98(\mathrm{~m}, 3 \mathrm{H}), 7.93(\mathrm{~d}, J=8.1 \mathrm{~Hz}, 1 \mathrm{H}), 7.81(\mathrm{~d}, J=12.2$ $\mathrm{Hz}, 1 \mathrm{H}), 7.47(\mathrm{~d}, J=8.0 \mathrm{~Hz}, 1 \mathrm{H}), 7.44(\mathrm{~d}, J=9.2 \mathrm{~Hz}, 1 \mathrm{H})$, $6.50(\mathrm{~d}, J=14.8 \mathrm{~Hz}, 1 \mathrm{H}), 5.75(\mathrm{~d}, J=12.2 \mathrm{~Hz}, 1 \mathrm{H}), 3.87(\mathrm{t}, J=$ $6.7 \mathrm{~Hz}, 2 \mathrm{H}), 1.88(\mathrm{~s}, 5 \mathrm{H}), 1.78-1.66(\mathrm{~m}, 5 \mathrm{H}), 1.41(\mathrm{~s}, 5 \mathrm{H})$; MS $m / z 799.0841\left(\mathrm{C}_{34} \mathrm{H}_{33} \mathrm{ClN}_{2} \mathrm{NaO}_{11} \mathrm{~S}_{3}{ }^{-}\right.$calcd 799.0838$)$. Dye 7 was obtained as a blue solid $(63.6 \mathrm{mg}, 42 \%)$ using the above-described procedure, with 2-chlormalodianil 2 as acroleine and indolenine $5(0.273 \mathrm{mmol}) .{ }^{1} \mathrm{H}$ NMR (700 MHz, DMSO- $\left.d_{6}\right) \delta 9.04(\mathrm{~d}, J=9.2 \mathrm{~Hz}, 1 \mathrm{H}), 8.58(\mathrm{~d}, J=13.6$ $\mathrm{Hz}, 1 \mathrm{H}), 8.46(\mathrm{~s}, 1 \mathrm{H}), 8.44(\mathrm{~d}, J=14 \mathrm{~Hz}, 2 \mathrm{H}), 8.23(\mathrm{~s}, 1 \mathrm{H})$, $8.11(\mathrm{~s}, 1 \mathrm{H}), 7.98(\mathrm{~d}, J=8.1 \mathrm{~Hz}, 1 \mathrm{H}), 7.88(\mathrm{~d}, J=9.4 \mathrm{~Hz}, 1 \mathrm{H})$, $7.39(\mathrm{~d}, J=8.3 \mathrm{~Hz}, 1 \mathrm{H}), 6.38(\mathrm{~d}, J=13.6 \mathrm{~Hz}, 1 \mathrm{H}), 6.31(\mathrm{~d}, J=$ $13.5 \mathrm{~Hz}, 1 \mathrm{H}), 4.31(\mathrm{t}, J=7.7 \mathrm{~Hz}, 2 \mathrm{H}), 3.70(\mathrm{~s}, 3 \mathrm{H}), 2.53(\mathrm{t}, J=$ $7 \mathrm{~Hz}, 2 \mathrm{H}), 1.97(\mathrm{~s}, 6 \mathrm{H}), 1.93-1.86(\mathrm{~m}, 2 \mathrm{H}), 1.78(\mathrm{q}, J=7.8$ $\mathrm{Hz}, 2 \mathrm{H}), 1.75(\mathrm{~s}, 6 \mathrm{H}) ;{ }^{13} \mathrm{C}$ NMR (176 MHz, DMSO-d 6 ) $\delta$ $175.12,174.74,146.91,146.77,145.70,145.64,143.23,140.34$, $139.49,134.12,129.81,129.61,127.32,127.22,123.02,122.20$, $122.00,118.95,111.82,110.24,100.03,99.47,51.20,50.74$, $49.07,44.08,31.55,26.80,26.56,26.44,22.62$; MS $\mathrm{m} / z$ $859.0730\left(\mathrm{C}_{35} \mathrm{H}_{35} \mathrm{ClN}_{2} \mathrm{Na}_{3} \mathrm{O}_{11} \mathrm{~S}_{3}{ }^{+}\right.$calcd 859.0779).

Dye $8(10.3 \mathrm{mg}, 7 \%)$ was afforded by applying the abovedescribed procedure, using 3 -anilino acroleine anil 3 and indolenine 4 (1.092 mmol). ${ }^{1} \mathrm{H} \mathrm{NMR}\left(700 \mathrm{MHz}\right.$, DMSO- $\left.d_{6}\right) \delta$ $8.80(\mathrm{~d}, J=9.1 \mathrm{~Hz}, 1 \mathrm{H}), 8.28(\mathrm{~s}, 1 \mathrm{H}), 8.01(\mathrm{~s}, 1 \mathrm{H}), 7.96(\mathrm{~d}, J=$ $6.3 \mathrm{~Hz}, 1 \mathrm{H}), 7.91(\mathrm{~d}, J=9.0 \mathrm{~Hz}, 1 \mathrm{H}), 7.42(\mathrm{~d}, J=8.2 \mathrm{~Hz}, 1 \mathrm{H})$, $7.33(\mathrm{~d}, J=9.2 \mathrm{~Hz}, 1 \mathrm{H}), 6.34(\mathrm{~d}, J=15.1 \mathrm{~Hz}, 1 \mathrm{H}), 6.28(\mathrm{t}, J=$ $12.6 \mathrm{~Hz}, 1 \mathrm{H}), 5.63(\mathrm{~d}, J=12.3 \mathrm{~Hz}, 1 \mathrm{H}), 3.78(\mathrm{t}, J=7.3 \mathrm{~Hz}$, $2 \mathrm{H}), 1.85$ (s, 6H), $1.74-1.68(\mathrm{~m}, 3 \mathrm{H}), 1.38(\mathrm{~s}, 6 \mathrm{H}) ; \mathrm{MS} \mathrm{m} / z$ $765.1234\left(\mathrm{C}_{34} \mathrm{H}_{34} \mathrm{~N}_{2} \mathrm{NaO}_{11} \mathrm{~S}_{3}{ }^{-}\right.$calcd 765.1228$)$. Dye 9 was synthesized according to the above-described procedure, using 3-anilino acroleine anil 3 and indolenine 5 (1.092 $\mathrm{mmol})$, affording dye 9 as a blue solid $(13.5 \mathrm{mg}, 9 \%) .{ }^{1} \mathrm{H}$ NMR (700 $\left.\mathrm{MHz}, \mathrm{DMSO}-d_{6}\right) \delta 9.00(\mathrm{~d}, J=9.1 \mathrm{~Hz}, 1 \mathrm{H}), 8.45(\mathrm{t}, J=13.3$ $\mathrm{Hz}, 2 \mathrm{H}), 8.43(\mathrm{~s}, 1 \mathrm{H}), 8.31(\mathrm{t}, J=13.1 \mathrm{~Hz}, 1 \mathrm{H}), 8.20(\mathrm{~s}, 1 \mathrm{H})$, 8.04 (s, 1H), $7.94(\mathrm{~d}, J=8.1 \mathrm{~Hz}, 1 \mathrm{H}), 7.78(\mathrm{~d}, J=9.3 \mathrm{~Hz}, 1 \mathrm{H})$, $7.25(\mathrm{~d}, J=8.2 \mathrm{~Hz}, 1 \mathrm{H}), 6.61(\mathrm{t}, J=12.5 \mathrm{~Hz}, 1 \mathrm{H}), 6.47(\mathrm{~d}, J=$ $13.9 \mathrm{~Hz}, 1 \mathrm{H}), 6.26(\mathrm{~d}, J=13.6 \mathrm{~Hz}, 1 \mathrm{H}), 4.23(\mathrm{t}, J=7.6 \mathrm{~Hz}$, $2 \mathrm{H}), 3.59(\mathrm{~s}, 3 \mathrm{H}), 2.54(\mathrm{t}, J=7.3 \mathrm{~Hz}, 2 \mathrm{H}), 1.94(\mathrm{~s}, 6 \mathrm{H}), 1.84$ $(\mathrm{q}, J=7.6,7.1 \mathrm{~Hz}, 2 \mathrm{H}), 1.80(\mathrm{q}, J=6.9 \mathrm{~Hz}, 2 \mathrm{H}), 1.70(\mathrm{~s}, 6 \mathrm{H})$; ${ }^{13} \mathrm{C}$ NMR (176 MHz, DMSO-d $\left.d_{6}\right) \delta 174.12,172.98,169.16$, $153.64,153.27,145.64,145.49,143.55,139.91,139.61,133.68$, $129.70,129.56,127.47,126.89,125.51,122.92,121.67,118.93$, $111.56,109.40,103.27,103.17,50.78,50.57,48.45,43.62$, 31.08, 29.65, 27.26, 26.95, 26.22, 22.46; MS $m / z 779.1369$ $\left(\mathrm{C}_{35} \mathrm{H}_{36} \mathrm{~N}_{2} \mathrm{NaO}_{11} \mathrm{~S}_{3}{ }^{-}\right.$calcd 779.1384$)$.

Preparation of NHS Esters 10-14. A solution of dye 6 (15 $\mathrm{mg}, 0.018 \mathrm{mmol}$ ), HSTU (9.7 $\mathrm{mg}, 0.027 \mathrm{mmol}$ ), and DIPEA (3.5 mg, 4-6 $\mu \mathrm{mol}, 0.027 \mathrm{mmol})$ in DMF $(555 \mu \mathrm{L})$ was stirred at room temperature (rt) for 1 day. The dye was precipitated in diethyl ether and centrifuged. The residue was dried in vacuum, and product 10 was afforded as a blue solid (11.9 mg, 72\%): MS $m / z$ 896.1011 $\left(\mathrm{C}_{38} \mathrm{H}_{36} \mathrm{ClN}_{3} \mathrm{NaO}_{13} \mathrm{~S}_{3}{ }^{-}\right.$calcd 896.1002).

Dye $7(15 \mathrm{mg}, 0.018 \mathrm{mmol})$ was reacted according to the above-described procedure to obtain $16.7 \mathrm{mg}$ (99\%) of dye 11: MS $m / z 910.1097\left(\mathrm{C}_{39} \mathrm{H}_{38} \mathrm{ClN}_{3} \mathrm{NaO}_{13} \mathrm{~S}_{3}{ }^{-}\right.$calcd 910.1158).

A mixture of dye $8(15 \mathrm{mg}, 0.019 \mathrm{mmol})$, DCC $(11.8 \mathrm{mg}$, $0.057 \mathrm{mmol})$, and NHS $(6.6 \mathrm{mg}, 0.057 \mathrm{mmol})$ in DMF (555 $\mu \mathrm{L}$ ) was stirred at $\mathrm{rt}$ for 1 day. After precipitation with diethyl ether and centrifugation, dye $12(16.7 \mathrm{mg}, 99 \%)$ was afforded as a blue solid: MS $m / z 862.1380\left(\mathrm{C}_{38} \mathrm{H}_{37} \mathrm{~N}_{3} \mathrm{NaO}_{13} \mathrm{~S}_{3}{ }^{-}\right.$calcd 862.1392).

Dye 9 (5.3 $\mathrm{mg}, 0.007 \mathrm{mmol})$ was reacted according to the previously described procedure to afford $3.8 \mathrm{mg}$ (64\%) of dye 13: MS $m / z 922.1353\left(\mathrm{C}_{39} \mathrm{H}_{39} \mathrm{~N}_{3} \mathrm{Na}_{33} \mathrm{O}_{13} \mathrm{~S}_{3}{ }^{+}\right.$calcd 922.1333).

Preparation of Bioconjugates. To a solution of holo-tf or ctx $(6.7 \mu \mathrm{M})$ in PBS ( $\mathrm{pH} 7.4)$ was added the NHS ester (1013 or ICC) from a stock solution of the respective dye in PBS (1-3 $\left.\mathrm{mg} \mathrm{mL}^{-1}\right)$, using a molar excess of the reactive dye $(2-5$ molecular equiv). The reaction mixture was gently shaken overnight at rt, and purification was performed with Sephadex columns (NAP25; Amersham) and PBS as the eluent. TLC (RP-C18) was used to confirm the absence of unbound dye. The $\mathrm{D} / \mathrm{P}$ ratios of dye $-\mathrm{tf}$ conjugates and dye-ctx conjugates were calculated using the absorption maximum method. ${ }^{53,54}$ Protein concentrations were calculated by measuring the absorbance at $280 \mathrm{~nm}$ using extinction coefficients estimated by the Expasy Protparam tool for ctx, and a molar absorption coefficient of $87000 \mathrm{~L} \mathrm{~mol}^{-1} \mathrm{~cm}^{-1}$ was used for tf. ${ }^{55}$ The purity of antibody conjugates and coupling to ctx were analyzed under nonreducing and reducing conditions using $13 \%$ polyacrylamide gel electrophoresis visualized by coomassie staining and recording the fluorescence signal on VersaDoc $4000 \mathrm{MP}$ (BioRad, Munich, Germany; setup for Cy3 detection: illumination with green LED, filter: $605 \mathrm{~nm}$ bandpass; Cy5 detection: illumination with red LED, filter: $695 \mathrm{~nm}$ bandpass). 
The PageRuler Prestained Protein Ladder (10-180 kDa) was purchased from Thermo Fisher Scientific.

SPR Binding Studies. Experiments were carried out on a Biacore X100 device (GE Healthcare, Freiburg, Germany). A carboxymethylated dextran chip (CM5-Chip; GE Healthcare, Freiburg, Germany) was fully coupled on Fc2 with EGFR Fcchimera (R\&D Systems, Wiesbaden-Nordenstadt, Germany), using the amine coupling strategy (EDC/NHS), HBS-EP (10 mM HEPES, pH 7.4; $150 \mathrm{mM} \mathrm{NaCl} 3 \mathrm{mM}$ EDTA; and $0.005 \% \mathrm{v} / \mathrm{v}$ surfactant $\mathrm{P} 20$ ) as a running buffer, and acetate ( $\mathrm{pH} 4.5)$ as a sample buffer for the ligand. The response level reached $\sim 5500 \mathrm{RU}$ for Fc2. Bevacizumab (Avastin; Roche/ Genentech) was coupled as a nonbinding control to Fc1, reaching $\sim 27000$ RU. Affinities were measured using a kinetic titration series (single-cycle kinetics) at $25{ }^{\circ} \mathrm{C}$, in which five ascending concentrations of conjugates 19-23 were injected consecutively for $120 \mathrm{~s}$ at $30 \mu \mathrm{L} \mathrm{min} \mathrm{m}^{-1}$, followed by a dissociation time of $600 \mathrm{~s}$ and two short pulses of $20 \mathrm{~s} 10 \mathrm{mM}$ glycin $\mathrm{HCl} \mathrm{pH} 2.5$ to regenerate the sensor surface. Therefore, the conjugates (19-23) were diluted in running buffer (HBS$\mathrm{EP})$ at concentrations of $1000,100,10,1$, and $0.1 \mathrm{nM}$, respectively. The signal of the Bevacizumab-treated flow cell was subtracted from the binding signal. Additionally, blank injects of running buffer only were also subtracted (double referencing) for each run. Measurements were performed in triplicate. Sensorgrams were analyzed by plotting the analyte concentration against the binding signal at the end of injection. The resulting isotherm was fitted to obtain the $K_{\mathrm{D}}$ values using the steady state model.

Cell Studies. For cLSM, epithelial human cancer cell line A431 (DSMZ No. ACC 91) and human lung carcinoma epithelial cell line A549 (DSMZ No. ACC 107) were routinely propagated in DMEM medium with $2 \%$ glutamine (Gibco BRL, Eggenstein, Germany), penicillin/streptomycin (Gibco BRL), and $10 \%$ fetal calf serum (FCS; Biochrom AG, Berlin, Germany) at $37{ }^{\circ} \mathrm{C}$ with $5 \% \mathrm{CO}_{2}$ and subcultured twice a week. For confocal microscopy, 27000 cells were seeded in each well of a $\mu$-Slides 8 Well (ibidi GmbH, Martinsried, Germany) and cultured at $37{ }^{\circ} \mathrm{C}$ for $24 \mathrm{~h}$. Thereafter, dye-labeled test substances were added to the cells at a final concentration of 1 $\mu \mathrm{M}$. Confocal images were taken with an inverted confocal laser scanning microscope, Leica DMI6000CSB SP8 (Leica, Wetzlar, Germany), with a $63 \times / 1.4$ HC PL APO CS2 oil immersion objective, at $37{ }^{\circ} \mathrm{C}$, using the LAS $\mathrm{X}$ software provided by the manufacturer. Images of different groups were acquired with the same laser and detector settings, using the Leica LAS AF software. Fluorescence detection was performed sequentially for each channel set with the acousto-optical beam splitter between 570 and $648 \mathrm{~nm}$ for the ICC dye and between 650 and $749 \mathrm{~nm}$ for the pentamethine dyes. ICC was excited using the $561 \mathrm{~nm}$ diode-pumped solid-state laser line, whereas the pentamethine dyes were excited with a $633 \mathrm{~nm}$ HeNe laser. For flow cytometric analysis, the A431 cell line was used and routinely propagated as described. The cells (100000 cells per well) were cultured in 24-well-plates at $37{ }^{\circ} \mathrm{C}$ for $24 \mathrm{~h}$. Thereafter, test substances were added for $10 \mathrm{~min}$ at a final concentration of $1 \mu \mathrm{M}$. After $10 \mathrm{~min}$ of incubation at $37^{\circ} \mathrm{C}$, the medium was removed and the cells were washed three times with PBS. For postincubation times, colorless cell culture medium was added and the cells were incubated at $37{ }^{\circ} \mathrm{C}$ for $0.5,1,3,5$, and $8 \mathrm{~h}$. Afterwards, the cells were detached by trypsin, transferred to an Eppendorf tube, and centrifuged at $140 \mathrm{~g}$ and $4{ }^{\circ} \mathrm{C}$ for $4 \mathrm{~min}$. The fluorescence of the cells was measured on BD Accuri C6 (Becton Dickinson, Heidelberg, Germany), and analysis was carried out using the BD Accuri C6 Software.

\section{ASSOCIATED CONTENT}

\section{Supporting Information}

The Supporting Information is available free of charge on the ACS Publications website at DOI: 10.1021/acsomega.6b00182.

NMR spectra, analytical HPLC chromatograms, absorption and fluorescence spectra, gel electrophoresis, SPR data, $K_{\mathrm{D}}$ values, and confocal microscopy images (PDF)

\section{AUTHOR INFORMATION}

\section{Corresponding Authors}

*E-mail: virginia.wycisk@fu-berlin.de (V.W.).

*E-mail: kai.licha@fu-berlin.de (K.L.).

\section{Notes}

The authors declare no competing financial interest.

\section{ACKNOWLEDGMENTS}

We acknowledge J. Montagu for proofreading and the Core Facility BioSupraMol of Freie Universität Berlin for their technical support. The authors thank the Helmholtz Association for funding this work through Helmholtz-Portfolio Topic “Technology and Medicine".

\section{REFERENCES}

(1) Lodish, H.; Berk, A.; Zipursky, S. L.; Matsudaira, P.; Baltimore, D.; Darnell, J. Molecular Cell Biology; W. H. Freeman, 2000; pp 673721.

(2) Grinstein, S.; Dixon, S. J. Ion transport, membrane potential, and cytoplasmic $\mathrm{pH}$ in lymphocytes: changes during activation. Physiol. Rev. 1989, 69, 417-81.

(3) Weissleder, R.; Tung, C. H.; Mahmood, U.; Bogdanov, A., Jr. In vivo imaging of tumors with protease-activated near-infrared fluorescent probes. Nat. Biotechnol. 1999, 17, 375-8.

(4) Alberts, B.; Johnson, A.; Lewis, J.; Morgan, D.; Raff, M.; Roberts, K.; Walter, P. Molecular Biology of the Cell; Garland Science, 2014; pp 439-1034.

(5) Golabek, A. A.; Kida, E.; Walus, M.; Kaczmarski, W.; Michalewski, M.; Wisniewski, K. E. CLN3 protein regulates lysosomal $\mathrm{pH}$ and alters intracellular processing of Alzheimer's amyloid-beta protein precursor and cathepsin D in human cells. Mol. Genet. Metab. 2000, 70, 203-13.

(6) Izumi, H.; Torigoe, T.; Ishiguchi, H.; Uramoto, H.; Yoshida, Y.; Tanabe, M.; Ise, T.; Murakami, T.; Yoshida, T.; Nomoto, M.; Kohno, $\mathrm{K}$. Cellular $\mathrm{pH}$ regulators: potentially promising molecular targets for cancer chemotherapy. Cancer Treat. Rev. 2003, 29, 541-9.

(7) Webb, B. A.; Chimenti, M.; Jacobson, M. P.; Barber, D. L. Dysregulated $\mathrm{pH}$ : a perfect storm for cancer progression. Nat. Rev. Cancer 2011, 11, 671-7.

(8) Gillies, R. J.; Raghunand, N.; Karczmar, G. S.; Bhujwalla, Z. M. MRI of the tumor microenvironment. J. Magn. Reson. Imaging 2002, $16,430-50$

(9) Zhang, X.; Lin, Y.; Gillies, R. J. Tumor $\mathrm{pH}$ and its measurement. J. Nucl. Med. 2010, 51, 1167-70.

(10) Miksa, M.; Komura, H.; Wu, R.; Shah, K. G.; Wang, P. A novel method to determine the engulfment of apoptotic cells by macrophages using pHrodo succinimidyl ester. J. Immunol. Methods 2009, $342,71-7$.

(11) Lee, R. J.; Wang, S.; Low, P. S. Measurement of endosome pH following folate receptor-mediated endocytosis. Biochim. Biophys. Acta, Mol. Cell Res. 1996, 1312, 237-42. 
(12) Lakadamyali, M.; Rust, M. J.; Babcock, H. P.; Zhuang, X. Visualizing infection of individual influenza viruses. Proc. Natl. Acad. Sci. U.S.A. 2003, 100, 9280-5.

(13) Adie, E. J.; Kalinka, S.; Smith, L.; Francis, M. J.; Marenghi, A.; Cooper, M. E.; Briggs, M.; Michael, N. P.; Milligan, G.; Game, S. A $\mathrm{pH}-$ Sensitive Fluor, CypHer 5, Used to Monitor Agonist-Induced G Protein-Coupled Receptor Internalization in Live Cells. BioTechniques 2002, 33, 1152-1157.

(14) Doherty, G. J.; McMahon, H. T. Mechanisms of endocytosis. Annu. Rev. Biochem. 2009, 78, 857-902.

(15) Ohkuma, S.; Poole, B. Fluorescence probe measurement of the intralysosomal $\mathrm{pH}$ in living cells and the perturbation of $\mathrm{pH}$ by various agents. Proc. Natl. Acad. Sci. U.S.A. 1978, 75, 3327-3331.

(16) Sunada, H.; Magun, B. E.; Mendelsohn, J.; Macleod, C. L. Monoclonal-Antibody against Epidermal Growth-Factor Receptor Is Internalized without Stimulating Receptor Phosphorylation. Proc. Natl. Acad. Sci. U.S.A. 1986, 83, 3825-3829.

(17) Sunada, H.; Yu, P.; Peacock, J. S.; Mendelsohn, J. Modulation of tyrosine, serine, and threonine phosphorylation and intracellular processing of the epidermal growth factor receptor by antireceptor monoclonal antibody. J. Cell. Physiol. 1990, 142, 284-92.

(18) Jaramillo, M. L.; Leon, Z.; Grothe, S.; Paul-Roc, B.; Abulrob, A.; O'Connor McCourt, M. Effect of the anti-receptor ligand-blocking 225 monoclonal antibody on EGF receptor endocytosis and sorting. Exp. Cell Res. 2006, 312, 2778-90.

(19) Masui, H.; Kawamoto, T.; Sato, J. D.; Wolf, B.; Sato, G.; Mendelsohn, J. Growth inhibition of human tumor cells in athymic mice by anti-epidermal growth factor receptor monoclonal antibodies. Cancer Res. 1984, 44, 1002-7.

(20) Wong, S. F. Cetuximab: an epidermal growth factor receptor monoclonal antibody for the treatment of colorectal cancer. Clin. Ther. 2005, 27, 684-94.

(21) Klohs, J.; Wunder, A.; Licha, K. Near-infrared fluorescent probes for imaging vascular pathophysiology. Basic Res. Cardiol. 2008, 103, 144-51.

(22) Alander, J. T.; Kaartinen, I.; Laakso, A.; Patila, T.; Spillmann, T.; Tuchin, V. V.; Venermo, M.; Valisuo, P. A review of indocyanine green fluorescent imaging in surgery. Int. J. Biomed. Imaging 2012, 2012, No. 940585 .

(23) Licha, K.; Resch-Genger, U. Probes for optical imaging: new developments. Drug Discovery Today: Technol. 2011, 8, e87-e94.

(24) Han, J.; Burgess, K. Fluorescent indicators for intracellular $\mathrm{pH}$. Chem. Rev. 2010, 110, 2709-28.

(25) Urano, Y.; Asanuma, D.; Hama, Y.; Koyama, Y.; Barrett, T.; Kamiya, M.; Nagano, T.; Watanabe, T.; Hasegawa, A.; Choyke, P. L.; Kobayashi, H. Selective molecular imaging of viable cancer cells with pH-activatable fluorescence probes. Nat. Med. 2009, 15, 104-9.

(26) Zhang, J. T.; Yang, M.; Li, C.; Dorh, N.; Xie, F.; Luo, F. T.; Tiwari, A.; Liu, H. Y. Near-infrared fluorescent probes based on piperazine-functionalized BODIPY dyes for sensitive detection of lysosomal pH. J. Mater. Chem. B 2015, 3, 2173-2184.

(27) Dolman, N. J.; Kilgore, J. A.; Davidson, M. W. A Review of Reagents for Fluorescence Microscopy of Cellular Compartments and Structures, Part I: BacMam Labeling and Reagents for Vesicular Structures. In Current Protocols in Cytometry; John Wiley \& Sons, Inc., 2001; pp 1-12.

(28) Miltsov, S.; Encinas, C.; Alonso, J. N. Nortricarbocyanines: New near-infrared pH-indicators. Tetrahedron Lett. 1998, 39, 9253-9254.

(29) Briggs, M. S.; Burns, D. D.; Cooper, M. E.; Gregory, S. J. A pH sensitive fluorescent cyanine dye for biological applications. Chem. Commun. 2000, 2323-2324.

(30) Cooper, M. E.; Gregory, S.; Adie, E.; Kalinka, S. pH-sensitive cyanine dyes for biological applications. J. Fluoresc. 2002, 12, 425-429.

(31) Zhang, Z.; Achilefu, S. Design, synthesis and evaluation of nearinfrared fluorescent $\mathrm{pH}$ indicators in a physiologically relevant range. Chem. Commun. 2005, 5887-9.

(32) El-Shishtawy, R. M.; Almeida, P. A new Vilsmeier-type reaction for one-pot synthesis of $\mathrm{pH}$ sensitive fluorescent cyanine dyes. Tetrahedron 2006, 62, 7793-7798.
(33) Xu, Y.; Liu, Y.; Qian, X. Novel cyanine dyes as fluorescent $\mathrm{pH}$ sensors: PET, ICT mechanism or resonance effect? J. Photochem. Photobiol., A 2007, 190, 1-8.

(34) Hilderbrand, S. A.; Kelly, K. A.; Niedre, M.; Weissleder, R. Near infrared fluorescence-based bacteriophage particles for ratiometric $\mathrm{pH}$ imaging. Bioconjugate Chem. 2008, 19, 1635-9.

(35) Patrick, M. J.; Janjic, J. M.; Teng, H.; O’Hear, M. R.; Brown, C. W.; Stokum, J. A.; Schmidt, B. F.; Ahrens, E. T.; Waggoner, A. S. Intracellular $\mathrm{pH}$ measurements using perfluorocarbon nanoemulsions. J. Am. Chem. Soc. 2013, 135, 18445-57.

(36) Beletskii, A.; Cooper, M.; Sriraman, P.; Chiriac, C.; Zhao, L.; Abbot, S.; Yu, L. High-throughput phagocytosis assay utilizing a $\mathrm{pH}$ sensitive fluorescent dye. Biotechniques 2005, 39, 894-7.

(37) Nordberg, E.; Friedman, M.; Gostring, L.; Adams, G. P.; Brismar, H.; Nilsson, F. Y.; Stahl, S.; Glimelius, B.; Carlsson, J. Cellular studies of binding, internalization and retention of a radiolabeled EGFR-binding affibody molecule. Nucl. Med. Biol. 2007, 34, 609-18.

(38) Nonaka, H.; Fujishima, S. H.; Uchinomiya, S. H.; Ojida, A.; Hamachi, I. Selective covalent labeling of tag-fused GPCR proteins on live cell surface with a synthetic probe for their functional analysis. J. Am. Chem. Soc. 2010, 132, 9301-9.

(39) Hua, Y.; Sinha, R.; Thiel, C. S.; Schmidt, R.; Huve, J.; Martens, H.; Hell, S. W.; Egner, A.; Klingauf, J. A readily retrievable pool of synaptic vesicles. Nat. Neurosci. 2011, 14, 833-9.

(40) Mathejczyk, J. E.; Pauli, J.; Dullin, C.; Resch-Genger, U.; Alves, F.; Napp, J. High-sensitivity detection of breast tumors in vivo by use of a $\mathrm{pH}$-sensitive near-infrared fluorescence probe. J. Biomed. Opt. 2012, 17, No. 076028.

(41) Jung, J.; Loy, K.; Schilling, E. M.; Rother, M.; Brauner, J. M.; Huth, T.; Schlotzer-Schrehardt, U.; Alzheimer, C.; Kornhuber, J.; Welzel, O.; Groemer, T. W. The antidepressant fluoxetine mobilizes vesicles to the recycling pool of rat hippocampal synapses during high activity. Mol. Neurobiol. 2014, 49, 916-30.

(42) Welzel, O.; Loy, K.; Tischbirek, C. H.; Tabor, A.; Gmeiner, P.; Kornhuber, J.; Groemer, T. W. The $\mathrm{pH}$ probe CypHer5E is effectively quenched by FM dyes. J. Fluoresc. 2013, 23, 487-94.

(43) Tsai, Y. T.; Zhou, J.; Weng, H.; Shen, J.; Tang, L.; Hu, W. J. Real-time noninvasive monitoring of in vivo inflammatory responses using a $\mathrm{pH}$ ratiometric fluorescence imaging probe. Adv. Healthcare Mater. 2014, 3, 221-9.

(44) Riedl, T.; van Boxtel, E.; Bosch, M.; Parren, P. W.; Gerritsen, A F. High-Throughput Screening for Internalizing Antibodies by Homogeneous Fluorescence Imaging of a pH-Activated Probe. J. Biomol. Screening 2016, 21, 12-23.

(45) Da Violante, G.; Zerrouk, N.; Richard, I.; Provot, G.; Chaumeil, J. C.; Arnaud, P. Evaluation of the cytotoxicity effect of dimethyl sulfoxide (DMSO) on Caco2/TC7 colon tumor cell cultures. Biol. Pharm. Bull. 2002, 25, 1600-3.

(46) Yamashita, S.; Furubayashi, T.; Kataoka, M.; Sakane, T.; Sezaki, H.; Tokuda, H. Optimized conditions for prediction of intestinal drug permeability using Caco-2 cells. Eur. J. Pharm. Sci. 2000, 10, 195-204.

(47) Jones, S.; Rappoport, J. Z. Interdependent epidermal growth factor receptor signalling and trafficking. Int. J. Biochem. Cell Biol. 2014, $51,23-8$.

(48) Tortorella, S.; Karagiannis, T. C. Transferrin receptor-mediated endocytosis: a useful target for cancer therapy. J. Membr. Biol. 2014, 247, 291-307.

(49) Reichert, S.; Welker, P.; Calderón, M.; Khandare, J.; Mangoldt, D.; Licha, K.; Kainthan, R. K.; Brooks, D. E.; Haag, R. Size-Dependant Cellular Uptake of Dendritic Polyglycerol. Small 2011, 7, 820-829.

(50) Mujumdar, S. R.; Mujumdar, R. B.; Grant, C. M.; Waggoner, A. S. Cyanine-Labeling Reagents: Sulfobenzindocyanine Succinimidyl Esters. Bioconjugate Chem. 1996, 7, 356-362.

(51) Mader, O.; Reiner, K.; Egelhaaf, H.-J.; Fischer, R.; Brock, R. Structure Property Analysis of Pentamethine Indocyanine Dyes: Identification of a New Dye for Life Science Applications. Bioconjugate Chem. 2004, 15, 70-78.

(52) Pauli, J.; Licha, K.; Berkemeyer, J.; Grabolle, M.; Spieles, M.; Wegner, N.; Welker, P.; Resch-Genger, U. New Fluorescent Labels 
with Tunable Hydrophilicity for the Rational Design of Bright Optical Probes for Molecular Imaging. Bioconjugate Chem. 2013, 24, 11741185.

(53) Mujumdar, R. B.; Ernst, L. A.; Mujumdar, S. R.; Lewis, C. J.; Waggoner, A. S. Cyanine dye labeling reagents: sulfoindocyanine succinimidyl esters. Bioconjugate Chem. 1993, 4, 105-11.

(54) Haugland, R. P. Coupling of Monoclonal Antibodies with Fluorophores. In Monoclonal Antibody Protocols; Davis, W. C., Ed.; Humana Press: Totowa, NJ, 1995; Vol. 45, pp 205-221.

(55) Hamilton, D. H.; Battin, E. E.; Lawhon, A.; Brumaghim, J. L. Using Proteins in a Bioinorganic Laboratory Experiment: Iron Loading and Removal from Transferrin. J. Chem. Educ. 2009, 86, 969. 